\title{
A Horror of the Vacuum: \\ An Overview of Old Age in Absurdist Literature
}

\author{
Pedro Querido
}

\begin{abstract}
The relevance and lasting influence of artistic expressions of the philosophical concept of the absurd has been highlighted by many scholars, notably by Martin Esslin in his pioneering work The Theatre of the Absurd and by Neil Cornwell in The Absurd in Literature. Interestingly, a cursory glance at the works of the practitioners of the absurd deemed most significant by Esslin (Adamov, Beckett and Ionesco, but also Pinget, Pinter and Hildesheimer) and Cornwell (Daniil Kharms, O'Brien, Kafka and again Beckett) reveals an intriguing pattern: virtually all of them have at least one important work with older people as main characters. In this chapter, my main aim is to understand why old age is so prominent in absurdist literature. First, I will examine some of the most archetypal interactions between the aged protagonists and their absurd universes, refining my working definition of the absurd (wherein "resistance" is an operative word) in the process. Then, after assessing the congruity of outliers and the pertinence of alternative causal explanations for this correlation, I will demonstrate that the thematization of aging characters in absurdist works owes much to the fact that old age may be seen as the radicalization of the human condition.
\end{abstract}

Key Words: the absurd, old age, aging, parable, resistance, human condition.

$* * * * *$

\section{On Horror}

When reading about aging, it is very common to find it described as being defined by ambivalence. ${ }^{1}$ This is a true and fitting assessment, but no less accurate is the fact that for most people, most of the time, there is nothing ambivalent about old age - it is all too often perceived as a dark, ominous cloud in the horizon, with no silver lining to redeem its bleakness. For Simone de Beauvoir, who wrote the first modern treatise on the topic, it is old age, and not death, that is the opposite of life. ${ }^{2}$ To mention only one more of the most extreme examples of this view, Kathryn White's somewhat apocalyptic reading of the theme of decay in the work

1. See, e.g., Small, The Long Life, 5; Davis, Age Rage and Going Gently, 185; Moody, "The Meaning of Life," 32.

2. Beauvoir, La Vieillesse, 565. 
of Samuel Beckett includes at least a dozen instances of the word "horror" or some derivative of it (usually the attribute "horrifying") to describe the representation of aging in Beckett's universe ${ }^{3}-$ a curiously persistent choice of words that, one is tempted to say, likely imparts more than Beckett's purified worldview.

Aging, it is known, is a universal phenomenon (indeed, the decline in bodily and cognitive functions it usually heralds is considered "normal up to a point"), ${ }^{4}$ but has it always evoked such overwhelming dread? Some thinkers remind us that this kind of antagonistic mindset, like any other mindset, must be informed by the specific sociocultural, economic and political environment it arises from. Old age, Harry Moody claims, is seen in today's Western capitalist societies as inimical to "the dominant ideological image of the ideal worker-consumer" trapped in "perpetual young adulthood," thus according to Moody the "modern horror of old age" is "a horror of the vacuum - the "limbo state' of inactivity." ${ }^{5}$ There is certainly much to be said about the corrosive effects that the axiomatic prescription of frenzied activity to the detriment of contemplation has on our perception of aging, ${ }^{6}$ but we should be cautious about equating the widespread aversion to old age with "modernity." For instance, in the early modern period "the horror of physical death and of decomposition ... was not restricted to postmortem decomposition; it was intra vitem, in illness, in old age." ${ }^{\prime 7}$ Indeed, a historical look back at the representations of aging in the arts readily demonstrates that there was never such a thing as a "golden age" of old age. ${ }^{8}$

The sheer complexity and heterogeneity of the concept of old age renders sweeping generalizations little more than useless as well as vulnerable to all manner of criticism, but it is safe to state that aging - for good or bad reasons, be it due to contingencies or necessities - tends to elicit feelings that are less than thoroughly positive, not to say at times bleak to the point of inducing one to denial in the interest of self-image preservation. This negativity causes it to chime with such motifs as the philosophical notion of the absurd and its corollary artistic manifestations - this link, though admittedly not self-evident, has been most inadequately explored, considering its remarkable potential. In the following

3. White, Beckett and Decay.

4. Hughes, "Should Aging Be Successful or Authentic?", 54-56.

5. Moody, "The Meaning of Life," 38, 12.

6. Moody, "The Meaning of Life," 21.

7. Ariès, Western Attitudes Toward Death, 41 (original emphases).

8. Thane, "The Age of Old Age," 9. 
pages, I propose to discuss the interplay between the theme of old age and the concept of the absurd. First, I will look at a sizable sample deemed representative of absurdist literature in order to conduct a preliminary analysis of some of the key themes and archetypes used. Then, I will consider a few possible reasons why old age and the absurd might interact so often. Finally, I will strive to make visible the theoretical substratum that holds this peculiar thematic correlation together.

\section{On the Absurd}

The importance of the literary expressions of the absurd - which was the "single unifying, pervasive concern" in the artistic and philosophical scenes of inter- and post-war Europe $^{9}$ - has been highlighted by many scholars, notably by Martin Esslin in his pioneering work The Theatre of the Absurd and by Neil Cornwell in his excellent book The Absurd in Literature. But what exactly is the absurd? It has time and again been conflated with nihilism, ${ }^{10}$ which, misleading though it may be, attests to the importance of the negative force behind it, one that entails an assault on one of the cornerstones of Western philosophical discourse: Reason. After all, the rise of the absurd in twentieth-century Europe went hand in hand with the "overall persistence of willful attempts at questioning the validity of the classical rationalist discourse."11 Indeed, the tension between rationality and the absurd is already present in Albert Camus's The Myth of Sisyphus (1942): for Camus, the absurd is "essentially a divorce" born of "the confrontation of the irrational and the wild longing for clarity." ${ }^{12}$

It is important to remember, however, that the absurd is "a relative not absolute notion." ${ }^{13}$ Esslin may argue that certain playwrights of the Parisian scene masterfully captured the Zeitgeist of the post-war years by writing about "the absurdity of the human condition itself in a world where the decline of religious belief has deprived man of certainties"14 - but he stops short of an allencompassing definition or narrative. He is careful to point out that the "Theatre of the Absurd," a term which he coined, is not a "self-proclaimed or self-conscious

9. Fotiade, Conceptions of the Absurd, 1.

10. As described in Cornwell, The Absurd in Literature, 4, and exemplified in Görner, Die Kunst des Absurden, 88.

11. Fotiade, 1.

12. Camus, The Myth of Sisyphus, 29, 20.

13. Hinchliffe, The Absurd, 90.

14. Esslin, The Theatre of the Absurd, 4, 339. 
school or movement"; ${ }^{15}$ Cornwell would later agree that "absurdism" is, far from an organized literary "movement," more akin to "a disposition." ${ }^{16}$ In fact, Michael Bennett, a scholar who has published two books on the subject, shows little regard for the absurd as a concept, revealing first a desire "to avoid the word and concept of the absurd," deeming its "'actual' definition" irrelevant, ${ }^{17}$ and later going as far as to denounce it as a "label" that perhaps "ought to be abandoned altogether." 18

In my opinion, a precise and useful definition of the absurd is both a thorny issue and a necessary evil; indeed, I have recently grappled with it in my bid for an understanding of absurdist art as resistance, having proposed the terms epistemological resistance (against rationality), political resistance (against absurdity), and ambivalent resistance (taking neither stance, or parts of both). ${ }^{19}$ For the time being, however, what matters to stress is that, terminological snags aside, there is plenty of evidence that attests to the lasting influence of the absurd. ${ }^{20}$ The absurd, it has been noted, cannot easily be overcome, ${ }^{21}$ and remains most relevant to this day. ${ }^{22}$ This means that a new reading of how the absurdist texts' protagonists face an absurd world could yield insights which must not necessarily apply only to the specific contexts which spawned those works, since the absurd may be said to possess "a timeless disposition or quality, which may be seen to pertain - at the very least here and there - throughout the history of literature." ${ }^{23}$

So who are those protagonists? When reading back to back the works of the practitioners of the absurd highlighted by Esslin (Arthur Adamov, Samuel Beckett, Eugène Ionesco, Jean Genet, Robert Pinget, Harold Pinter, Wolfgang Hildesheimer) and Cornwell (Beckett, Daniil Kharms, Flann O’Brien, Franz Kafka),

15. Esslin, 4.

16. Cornwell, 99.

17. Bennett, Reassessing the Theatre of the Absurd, 4, 3.

18. Bennett, The Cambridge Introduction, 2. This despite the fact that both books use the term in their respective titles.

19. See Querido, "From Kharms to Camus."

20. See, e.g., Esslin; Cornwell; Bennett, Cambridge Introduction. For a rather reluctant (and therefore all the more persuasive) admission of this, see Hinchliffe, 92.

21. Görner, 136.

22. Cornwell, 312.

23. Cornwell, 310. 
something stands out: virtually all of them wrote one or more important works which have at least one older person as a central character. To name but a few instances, Ionesco's Les Chaises, Pinter's A Slight Ache, Hildesheimer's trilogy Spiele, in denen es dunkel wird, Adamov's Le Ping-Pong, and Pinget's La manivelle and Lettre morte all feature older people; the death of an old person is central to the plot of Kharms's The Old Woman and O'Brien's The Third Policeman; and most of Beckett's work from the 1950s onwards relies heavily on older protagonists.

Is this just a coincidence? Or is the theme of old age uniquely apt for the portrayal of a lonely human being's struggle with the absurd? The latter hypothesis would seem to explain the constant and systematic use of the theme of old age in absurdist literature. What is striking, however, is how little research has been conducted on this particular correlation. This may not have to do solely with the relative unpopularity of the concept of "absurdism" in academic circles, but with a general lack of literary research on old age as well.

\section{On Old Age}

A superficial diachronic analysis of the relationship between old age and Western literary studies reveals a telling paradox: although old age as a theme has always been present in the arts, ${ }^{24}$ its study in literature "is a relatively recent phenomenon." ${ }^{25}$ Indeed, Oliver Davis notes that although "growing old is, at least in principle, a universal human possibility . . . it has remained a minority interest in literary studies, especially as opposed to, for example, the related themes of death and illness and the contrasting theme of childhood."26

This thematic subordination could perhaps be explained by the fact that old age "is infinitely adaptable and frequently shades into other motifs," 27 but according to Davis its origins run deeper than that: old age, never having been more than "a secondary or incidental concern in Western attempts to theorize human subjectivity," is refused the "intrinsic meaning" attributed to death, which, unlike old age, is unfailingly considered key to understand the human condition. ${ }^{28}$

There are surely few examples as representative of this as Christopher Ricks's Beckett's Dying Words (1993). Remarkably, this book-length study of the theme of death in the work of Samuel Beckett (whose literary output famously includes an

24. See Thane.

25. Davis, 21.

26. Davis, 10.

27. Jochum, "The Poet and Old Age," 18.

28. Davis, 10, 11. 
overwhelming number of older people as protagonists) contains only a few passing and rather inconsequential references to old age. ${ }^{29}$ In a more recent book on Beckett and Death, which features a collection of essays that covers a wide range of possible angles and topics within the general theme of finitude, aging is only mentioned in the last chapter, and very discreetly at that (and, what is more, mainly from a biographical perspective). ${ }^{30}$

It is not easy to reconcile the ubiquity of old age in literature with the age-old silence from the academic world, one which is evident even in the undeniably profuse literary criticism on Beckett's work. This discrepancy was not lost on Kathleen Woodward, who noted that "few literary critics have turned their attention to Beckett's portraits of old age," focusing instead on the thematization of death. ${ }^{31}$ This happens to be true of philosophy in general as well, ${ }^{32}$ partly due to the "dichotomies," "dramas," and the very "inconceivability of death." ${ }^{33}$

Taking into account both the conceivable relevance of the absurd for considerations about aging and the ubiquity of old age in absurdist literature, it would seem to be appropriate to carry out a comparative analysis and look for patterns, hoping to find similarities in the different answers to the question which Esslin claims to be at the heart of each play of the Theater of the Absurd: "How does this individual feel when confronted with the human situation?"34

\section{Three Different Reactions to the Absurd}

One common response to the absurd seems to be not to respond to it at all. Very often, the older characters that populate absurdist literature represent the human being in denial of their frail condition, thus embodying what Sartre disdainfully called mauvaise foi. In these instances, the older character is depicted as being stubbornly, sometimes even cheerfully, oblivious of the absurdity of unthinking life and of the nothingness trailing in the wake of ever-encroaching death. To make matters worse, by the end we realize that enlightenment in the form of anagnorisis is not only elusive but indeed likely impossible, so there seems to be no possibility for any kind of redemption.

29. Ricks, Beckett's Dying Words, 34, 43.

30. Barfield, Feldman, and Tew, Beckett and Death. The chapter in question is Steven Matthews's text on "Beckett's Late Style."

31. Woodward, "Transitional Objects and the Isolate," 140.

32. Smart, 1.

33. Bavidge, "Feeling One's Age," 208.

34. Esslin, 342. 
A typical example of this is Adamov's Le Ping-Pong, where this lack of selfawareness is obvious not only in the last scene, which has been interpreted as a metaphor for the "senile whiling away of the remaining time before death reduces everything to final absurdity," ${ }^{35}$ but also in the character of the Old Man, who finds chatting to be an adequate substitute for actual knowledge and who refuses to let the doctor in even though his death is nigh. ${ }^{36}$

Other occurrences of this paradigm can be found in Hildesheimer's absurdist plays. The tenuousness of the older couple's grasp on their ever-darkening reality in Die Uhren (a play that culminates with their clock-imitating shenanigans) leaves no room for doubt. The models posing for the painter Adrian in Landschaft mit Figuren inexplicably age greatly between acts while Adrian and his wife remain the same, and the way that those models sheepishly allow themselves to be sold, packed, and prepared for shipping is indicative of their less-than-perfect cognizance of their situation. Finally, the elderly but childlike brothers Asbach in Pastorale oder Die Zeit für Kakao, who personify the time-honored adage of old age as a "second childhood," 37 seem to be little more than receptacles for their guileless, predatory, unmitigated ids.

Less obviously, Beckett's Krapp's Last Tape also pokes fun at an older man's foolhardy mocking of the recorded musings of his younger selves, never realizing that he goes on behaving in the exact same foolish manner as before. ${ }^{38}$ In addition, Beckett's successive rewritings of the play testify to his efforts to make his character more clownish, ${ }^{39}$ and in the end Krapp "never acquires the selfawareness that might afford a tragic dimension." 40

The prevalence of comedy in these works is telling: there is a sense of condemnation of the characters' attitudes that elicits derision from the part of the audience. For instance, Adamov's Old Man is a faithful incarnation of the 17th-century stereotype that perceives old men as "financially greedy, physically lustful, self-important, talkative and meddling individuals," who for that reason "were the butt of jokes and targets of mockery." 41 The main characters Arthur and Victor do not fare much better, engrossed as they are in the "futile frenzy of

35. Esslin, 86.

36. Adamov, Théâtre II, 165.

37. Parkin, "The Ancient Greek and Roman Worlds," 46.

38. Ackerley and Gontarski, The Grove Companion to Samuel Beckett, 303.

39. Ackerley and Gontarski, 303.

40. Ackerley and Gontarski, 304.

41. Botelho, "The 17th Century," 135. 
activity" that is their "purposeless" game. ${ }^{42}$ At one point, Arthur sits on the ping pong table and crosses his arms in protest, ${ }^{43}$ just like a child might, which again plays on the ancient trope of the putative "childishness" of old age.

Having said that, on the whole the literature of the absurd is both tragic and comic, "perhaps in equal measure," 44 since absurdist literary texts tend to be "existential and ironic, serious and playful." ${ }^{45}$ Indeed, according to Esslin, the Theater of the Absurd "transcends the categories of comedy and tragedy." 46 A particularly stirring example of a less derisive portrayal of denial is Pinter's $A$ Slight Ache, where Edward becomes obsessed with the matchseller who stands outside his house, a "poor, harmless old $\operatorname{man}^{\prime 47}$ with whom he symbolically switches places in the end. Edward refuses to ease the transition by drawing an insuperable line between him and the matchseller: commenting on the old man's muteness, he says that "I should be the same, perhaps, in his place. Though, of course, I could not possibly find myself in his place." ${ }^{48}$

A second frequent response to the absurd also involves a refusal, but one of a more complex nature: the old man, dimly if deficiently aware of his dire situation, shirks from a full recognition of it by talking on and on, by endlessly creating stories, by building a sand castle of meaning with his words, hoping to take shelter in it when the tidal wave that looms on the horizon comes crashing down. This hopeless exercise, it must be said, has its share of illustrious proponents. Camus may have claimed that "[c]reating or not creating changes nothing," 49 but his actual literary output shows no sign that he really believed in that. Instead, he argued, not too convincingly, ${ }^{50}$ that even in an absurd world art is necessary, because art, according to Camus, points the way out of the absurd ${ }^{51}-$ a notion that follows in the footsteps of such philosophers as Arthur Schopenhauer and Friedrich Nietzsche.

42. Esslin, 86.

43. Adamov, 179.

44. Cornwell, 33.

45. Görner, 137 (my translation, original emphasis).

46. Esslin, 347.

47. Pinter, Plays, 178.

48. Pinter, 188. For an elaboration of this argument, see Querido, "Considering Old Age and the Absurd."

49. Camus, 94.

50. Schaper, Ironie und Absurdität als philosophische Standpunkte, 80-81.

51. Schaper, 90. 
For Beckett, however, that is mostly a hearty dose of wishful thinking. ${ }^{52}$ Despite this, the chattering aged men and women in Beckett's work spin an endless web of clumsy words (see Beckett's trilogy and later novels) and resort to perennial storytelling (see, e.g., Endgame and Embers), in order to "hang on," to transcend and overcome the absurdity of life and death through creation. They would see in Camus's statement that "[i]f something brings creation to an end, it is not the victorious and illusory cry of the blinded artist: 'I have said everything,' but the death of the creator" 133 not evidence of the absurd, but a glimmer of hope: as long as there is creation, there is life.

An apt example of this is Hamm from Beckett's Endgame, who famously says that "it's time it ended. . . . And yet I hesitate, I hesitate to . . . to end" 54 - and his way to put off that end is by telling stories. Since in Beckett "time is concentrated entirely in the idea of the finish never finishing," ${ }^{55} \mathrm{Hamm}$, an avid storyteller just like his father, ${ }^{56}$ may feebly consider finishing his story, but in the next moment contemplates bringing in new characters, ${ }^{57}$ wishing for a reprieve similar to Scheherazade's in her One Thousand and One Nights.

And yet these almost pathetic attempts seem to yield some results. Although Hamm's "[o]ld endgame lost of old"58 is said to be nearing its end, the circular structure of the play could belie this interpretation. Each word in Beckett's firstperson narratives keeps its often-moribund speaker alive for a little longer, because "to speak is not to die just yet." 59 And the "irrepressible urge to speak" of the old men in Pinguet's La manivelle might show all the scars left by the enemy in Pinget's works: "time, old age, [and] a faulty memory," 60 but ultimately "the old tune," threatening to be drowned out by the noises of the street, "rises triumphantly," ${ }^{61}$ winning out against all odds.

An intriguing variation on this motif is discernible in Hildesheimer's radio work Monolog. The speaker, who lies in bed throughout, begins by declaring: "Now -

52. Görner, 94.

53. Camus, 111.

54. Beckett, The Complete Dramatic Works, 93.

55. Jaccard, "Daniil Kharms," 65.

56. Beckett, 103-105, 101-103.

57. Beckett, 118.

58. Beckett, 132.

59. Jaccard, 58.

60. Reid, "Robert Pinget," 100.

61. Pinget, Lettre morte / La manivelle, 156 (my translation). 
now I am becoming old, now it begins." ${ }^{62}$ The circularity of the plot, a popular device among the writers analyzed here, does not manifest itself toward the end but instead, rather quirkily, already in the second sentence: "Always now, always in this hour of the night." ${ }^{13}$ This unequivocal declaration of alertness to his reality is dampened by his enthusiasm for seemingly prosaic matters such as the weather report and the road condition report - these automatic, endlessly replayed messages relayed by a telephone call represent his only (willful) contact with the outside world, meagre as it is. What is interesting and somewhat paradoxical about this is that he finds his solace and respite not in fiction but in reality; he continuously seeks factual if fairly trivial information about the "real world" as a distraction from loftier projects, such as coming to terms with possible guilt, regret, and the past in general.

One last common reaction to absurdity that I would like to mention here, if only to test the prevalent idea that absurdity must be existentialist and atheist, is faith. Camus, it is well known, derided Søren Kierkegaard for deifying "the irrational," leading him to give "God the attributes of the absurd: unjust, incoherent and incomprehensible," ${ }^{14}$ and Karl Jaspers for likewise believing that "the absurd becomes god ... . and that inability to understand becomes the existence that illuminates everything." ${ }^{65}$ Esslin's groundbreaking if controversial notion of the Theater of the Absurd rested upon the opinion that the "decline of religious faith" brought about by the world wars was a decisive factor behind it, ${ }^{66}$ a perspective held by other critics since, ${ }^{67}$ some of whom would even consider it "axiomatic that for Absurdity to exist, God must be dead." ${ }^{68}$

However, this view would deprive the absurdist canon of some of the most singular writers to have been associated with it, most notably Daniil Kharms and Flann O'Brien. Their inclusion in this lot - which, it goes without saying, is far from consensual - has sound theoretical backing. As I have already briefly mentioned, my own working definition of the absurd is inextricable from, to borrow a felicitous phrase for the succinct way it perfectly describes something quite

62. Hildesheimer, Die Hörspiele, 287 (my translation).

63. Hildesheimer, Die Hörspiele, 287 (my translation).

64. Camus, 37.

65. Camus, 31.

66. Esslin, 4.

67. E.g., Wellwarth, The Theater of Protest and Paradox, $\mathrm{x}$.

68. Hinchliffe, vii. 
complex and frustratingly nuanced, the "critique of extreme rationalism." 69 And the cause against the excesses of rationality can draw as much support from the bleakest atheists, like Emile Cioran, ${ }^{70}$ as from the most devout believers. For instance, a "concept of potential or actual relevance to some practitioners of the absurd is that known as 'negative theology' (or the via negativa),"71 and, according to Cornwell, such a link between faith and absurd can be traced as far back as to Tertullian: "the world is absurd, and therefore faith is possible."72 This is an analogous reasoning to the one that leads to the "blind leap of religious faith" that comprises one of the ways of dealing with the absurd ${ }^{73}$ and that drew such painstaking vitriol from Camus.

Thus, the absurdist opposition to rationality (or at least hyperrationality) would in fact appear to synergize well with faith, seeing that it is one of the possible "nonrational sources of belief."74 As Ramona Fotiade put it in her work on the absurd in existential (as opposed to the existentialist variety, which by default is atheistic) thought, faith, when informed by the absurd, can be "an alternative mode of understanding," "an alternative type of knowledge, a "second dimension of thought,' within which truth no longer depends on necessary, universal judgements or on the principles of rational demonstrability."75 According to this line of reasoning "the contingent, 'absurd' existence of the living individual" co-occurs and symphonizes with "the equally 'absurd' (logically unverifiable) existence of God."76

These considerations might help shed some light on two most perplexing works: Kharms's The Old Woman and O'Brien's The Third Policeman. These have

69. Used by Gerould ("Contexts for Vatzlav: Mrozek and the Eighteenth Century," 21) when discussing Sławomir Mrożek's play Vatzlav and its fruitful engagement with Enlightenment thinkers. He argues that such a critique should be seen as distinct from what leads others to label him as an absurdist playwright, but, as I have suggested in the past and according to my proposed thematic definition of the absurd, the two are not only compatible but indeed complementary (Querido, "From Kharms to Camus," 790).

70. Cioran, A Short History of Decay, 10.

71. Cornwell, 10 (original emphasis).

72. Cornwell, 10.

73. Cornwell, 23.

74. Nathanson, The Ideal of Rationality, 73.

75. Fotiade, 212, 217.

76. Fotiade, 54. 
the particularity of having older people not as protagonists but as inscrutable, quasi-supernatural characters: in both of these works, the older person dies early on but miraculously continues functioning in one way or another, remaining a key element throughout the rest of the plot. In O'Brien's The Third Policeman, Old Mathers is murdered, only to reappear later as the ineffable and omnipotent Policeman Fox; in a way, "the killing of the old man creates God." 77 In the end, because the protagonist is unwilling and unable to repent, redemption is impossible, and the plot's circular structure indicates that he is doomed to relive his absurd hell ad infinitum. In The Old Woman, the death of the eponymous character, who has sensibly been interpreted as symbolizing both time and death, ${ }^{78}$ does not seem to have a profound effect on Kharms's protagonist, who, far from a saint but hardly responsible for her death, is more concerned with the disposal of the body. After that is done, however, his reaction is to bow his head and pray. ${ }^{79}$ This piteous attitude seems to earn him respite: in stark contrast to The Third Policeman, the story ends abruptly, immediately after the prayer.

Writers such as O'Brien and Kharms are adept at bringing together the absurd and faith in the form of negative ontology. While O'Brien critics might not have yet explored this connection in great detail, the same cannot be said of Kharms scholars: Neil Carrick, who has focused on the spiritual aspect of the Russian author's works, contends that they put forward "an absurdist theology," as "they defy Reason" and thematize belief in the supernatural. ${ }^{80}$ Unlike what would generally be the case in instances of the better-known brand of absurdist literature, such belief is not only to be parodied by the avant-gardist writer; the intimation that the subtext of The Old Woman is "arguably religious" 81 or even bolder claims like those stating that "[f]or Kharms, faith in the miraculous constitutes the meaning and purpose of life" 82 are bound to be met with agreement by anyone familiar with his all-important diaries and notebooks. ${ }^{83}$

\section{On resistance and outliers}

77. Brivic, "The Third Policeman as Lacanian Deity," 117.

78. Giaquinta, "Elements of the Fantastic," 136, 142.

79. Kharms, Today I Wrote Nothing, 112.

80. Quoted in Cornwell, 177 (original emphasis).

81. Cornwell, 162.

82. Ilya Levin quoted in Anemone, "The Anti-World of Daniil Kharms," 92.

83. See Kharms, "I Am a Phenomenon Quite Out of the Ordinary." 
Yet the most remarkable reaction to absurdity is the one that is most conspicuously absent. For Beauvoir, talking about "calm acceptance" of growing old amounts to nothing but insincere wordplay; ${ }^{84}$ thus for her "calm is not acceptance but denial." ${ }^{85}$ And indeed, when searching for the most common attitudes of the older characters who are faced with the frailty and absurdity of the human condition, serene acceptance, or even grudging resignation, is surprisingly hard to find.

Before we go down the rabbit hole uncovered by this insight, we ought to have another look at the "faith" camp and see it for what it is and for what many have deemed it: an outlier. Due to the complex nature of literary research, the results of its inquiries, regardless of how scientifically sound the work that precedes them was, cannot always yield neat Venn diagrams with relatively straightforward intersections such as the one I sought to give form to with my formulation of absurdist literature as defined by epistemological - political ambivalent resistance. The scrumptious prospect of the kind of clear and elegant solution provided by a mathematical theorem has no place here; remainders, if the research is truly carried out in an honest manner, will always figure in our work - and indeed ought to be seen as a vital part of it.

Kharms and O'Brien, then, are such remainders - and this despite the valid arguments that could be enlisted to their inclusion in our absurdist corpus, namely their skepticism toward rationalism. As we have seen, what the two writers' most important absurdist works (which also happen to broach otherworldly phenomena) - Kharms's The Old Woman and O'Brien's The Third Policeman - have in common is precisely what separates them from the works from other practitioners of the absurd who thematize old age: it is not the protagonists who are presented as "old," but instead seemingly marginal characters who supposedly die in the very beginning of their respective stories for no apparent reason, only to later undergo a supernatural transformation and reappear, like poltergeists, to haunt the homodiegetic protagonists.

If this paramount difference were not found to be convincing enough to disregard these works in this fairly specific study on absurdist literature, the key concept of resistance dispels all doubts. In accordance with what Camus pointedly argues, where there is resignation there cannot be a true acknowledgement of the absurd - just like, for Beauvoir, there can be no "calm acceptance" of something like old age. There are still important absurdist elements in Kharms

84. Beauvoir, 566.

85. Davis, 48. 
and O'Brien, such as the hopelessness of human agency, but there is also somehow room for real hope without real agency - a paradox only surmountable by a leap of faith. The ending of The Old Woman is atypical (the terms of comparison, just to be clear, being the other absurdist works where the theme of old age is handled in some way or another) in that the narrative ends with a simple prayer - one which, in a way, works as a prayer for protection, shielding its guilt-ridden utterer, since the offending reality that prompted it collapses immediately afterwards (i.e., the "author" intervenes and the manuscript ends). Likewise, the circularity of plot so beloved by the practitioners of the absurd is distorted in The Third Policeman by its overt ethical dimension - upon O'Brien's own admission, "all the queer ghastly things which have been happening to him [the protagonist of The Third Policeman] are happening in a sort of hell which he earned for the killing." ${ }^{\prime 86}$

So while I still maintain that it can be fruitful to read writers such as Kharms and $O^{\prime} B$ Brien through the lenses of the absurd, their creations cannot be said to be thematically representative of the artistic efforts that we mean to discuss when we talk about absurdist literature. Their work is just as close, if not closer, to the Christian tradition of literary nonsense epitomized by G. K. Chesterton than to the likes of Beckett and company - even though, as I have said, following scholars like Cornwell, such comparisons remain very much legitimate and may often be useful.

This distinction is made even clearer when we consider how, while for the existential thinkers studied by Fotiade resignation is what "more adequately designates what seems to be the only sensible attitude when man comes to confront the implacable truth of human mortality, ${ }^{187}$ such an attitude is in such short supply elsewhere in absurdist literature. The absurd, or at least its "ambivalently resistant" (and in my opinion most stimulating) strand, is simply incompatible with the resignation.

This means that, for the purposes of the present study, my previous efforts to define the absurd as resistance should be refined to exclude purer instances of "epistemological resistance," because they tend ${ }^{88}$ to be inimical to what I consider to be a more representative (or at least interesting) worldview, namely the idea

86. O'Brien quoted in Bennett, Afterlife and Narrative in Contemporary Fiction, 64.

87. Fotiade, 77.

88. A noteworthy exception to this might be Beckett's parody of the Cartesian doubt, Watt. 
that the absurd ought to be both acknowledged and resisted - that is, faced," in both senses of the word.

My working definition should also leave the opposite end of the spectrum, "political resistance" (which is constitutive of later works by Camus, the Eastern European Theater of the Absurd as described by Esslin, and the fascinating case of modern dystopias), out of account. From a theoretical standpoint, their critique of rationalism is as a rule ${ }^{89}$ greatly curtailed by an activist instrumentalization of Reason, which makes this strand of resistance something of an "odd one out" in my three-pronged definition of the absurd. This is especially true when we bear in mind the purposes of this particular article; the works featuring the absurd as political resistance simply do not tend to thematize old age in any meaningful way, apart from producing understandable if simplistic depictions of older characters as stand-ins for reactionary zeal, that is, authority figures who try to dampen the younger generation's revolutionary ardor.

\section{On possible causes for the correlation between old age and the absurd}

It might look tempting to use these early findings in order to devise some sort of tentative taxonomy, namely by grouping the different reactions to the absurd into broad categories, such as "denial," "narrativization," "faith," and "resistance." However, the preceding pages were not meant as an attempt at a rigorous systematization of such reactions. Their purpose is twofold. On the one hand, I sought to help delineate the boundaries of the concept of the absurd and thus the working definition of absurdist literature (which for the purposes of this article includes only those works that express the prototypical reaction to the absurd, what I termed ambivalent resistance - i.e., that both clearly acknowledge and at least partly resist the philosophical concept of absurdity). On the other hand, I wished to forage for food for thought the better to tackle the great conundrum that drives my research: why is old age so prevalent in absurdist literature?

This curious correlation is not easily unraveled. Could it merely be that the old are seized upon as a comic trope, ${ }^{90}$ one that calls upon a rich history in folklore and nonsense literature, ${ }^{91}$ such as in Lear's limericks? ${ }^{92}$ As we have discussed, laughter (in all its forms and manifestations, notoriously including the bitter or mirthless variety) lies at the essence of the absurd, and often the antics of older

89. Here too we find a most intriguing exception: Zamyatin's We.

90. Rooke, "Old Age in Contemporary Fiction," 248.

91. Cornwell, 162.

92. Thomas, "The Sense of Nonsense Verse," 120. 
characters, not uncommonly inspired by the (mostly negative) stereotypes and commonplaces that are appended onto their age cohort, undeniably provide some of the comic relief that is useful, perhaps even essential, when one wants to gaze into the abyss without necessarily falling into it. However, and again as we have seen, this cannot be the main (let alone the only) reason why old age figures so prominently in absurdist literature. While the comic potential of old age is overtly prodded at in works like Pinget's La Manivelle or Bruno Schulz's "The Old Age Pensioner," one would be hard-pressed to find an analogous use of that theme in Beckett's Rockaby, Pinter's A Slight Ache, or Hildesheimer's Monolog.

The aforementioned recourse to unflattering stereotypes of old age might point to a different prima causa: is aging thematized for the sake of venting ageist proclivities? lonesco's infamously prolific autobiographical statements might nudge us further in that direction. That his disparaging portrayal of an elderly couple in Les Chaises is an unambiguously derisive caricature of old age ${ }^{93}$ is clear enough, but Michel Lioure claims that it was colored by the author's personal obsession with (and horror of) finitude ${ }^{94}$ - thus, the Old Man in Les Chaises "is the image of the decrepitude that lonesco has always feared." ${ }^{\prime 25}$

However, that sort of attitude is far from representing the norm. It is famously not the case with Beckett, to name only the most obvious example. More to the point, the textual evidence often belies this assumption. Although absurdist literature is well known for such by now long-established ploys as "complicating immersion in the narrative world and foregrounding the fictional status of the text," ${ }^{\prime 96}$ the great number of instances of older characters as first-person narrators - or as a solitary presence on stage, or as virtually the sole voice to be heard in a radio work - certainly encourages the cultivation of a great deal more empathy than if those characters were always put at arm's length and we were not given a

93. Lioure, "Les Chaises," 124.

94. Lioure, "Les Chaises," 122.

95. Lioure, "Le Vieux," 632 (my translation). Kharms is an analogous case, as he made a point of writing the following entry in one of his notebooks: "I hate children, old men and old women, and reasonable older individuals" (Kharms, Today I Wrote Nothing, 252). This may go some way towards explaining his older characters' propensity to serious injury in so many of his vignettes.

96. Gavins, Reading the Absurd, 133. She is specifically referring to absurdist prose, but I think it is obvious that this general idea is just as valid and applicable to absurdist works written for media like theater, radio, or television. 
proper insight into their minds' workings. ${ }^{97}$ In a word, it is not by chance that absurdist literature (at least when understood in the terms put forward in this article) is more likely to be described as tragicomic than as purely farcical.

This begs the opposite question: if first-person narrators are so prevalent, and if aging is represented and dramatized so often, perhaps it is the authors' own coming to terms with aging that prompts a change in their writing practices what Edward Said called "late style." evidence, as opposed to relying too heavily on biographical readings, but in this regard it is worth mentioning that "by the time of writing of lonesco's Les Chaises, Pinter's A Slight Ache, Hildesheimer's Landschaft mit Figuren and Die Uhren, Kharms's The Old Woman, Adamov's Le Ping-Pong, O'Brien's The Third Policeman, Pinget's La manivelle and Lettre morte, and many of Beckett's works with older protagonists from the 1950 s and 1960s, their respective authors were all relatively young." 99

So there must be better reasons for the existence of this correlation - namely, the possibility that having aging characters face an absurd world adds poignancy to that confrontation due to the immediacy of the danger of utter extinction, a fear kept alive by the ancestral link between "time" and "death." ${ }^{100}$ In the closing section of this article, I will test the theoretical soundness of this hypothesis.

\section{On form, and on old age as the radicalization of the human condition}

I propose to begin by examining not only the themes but also the form of the absurdist works. The pertinence of that approach is corroborated by Esslin's claim regarding the close relationship between form and content in absurdist drama. Dramatists with a similar Weltanschauung, such as Jean-Paul Sartre and Camus,

differ from the dramatists of the Absurd in an important respect: they present their lucid and logically constructed reasoning, while the Theater of the Absurd strives to express its sense of the senselessness of the human condition and the inadequacy of the rational approach

97. Hildesheimer goes even further and states that in absurdist prose there is actually a greater identification with the protagonist than in "regular" novels, because the protagonist's absurd reality is the also the reader's (Hildesheimer, Vermischte Schriften, 58).

98. Said, On Late Style, 6.

99. Querido, "Considering Old Age and the Absurd," 78.

100. Fotiade, 117. 
by the open abandonment of rational devices and discursive thought. . .. It is this striving for an integration between the subject-matter and the form in which it is expressed that separates the Theatre of the Absurd from the Existentialist theatre. ${ }^{101}$

Indeed, Beckett himself, after all "the key and the link within absurd literature,"102 argued, when discussing Joyce's then-titled Work in Progress, that "the form, structure, and mood of an artistic statement cannot be separated from its meaning." ${ }^{\prime 103}$

In his recent analyses of the absurd in its artistic manifestations, Michael Bennett set out to study them in structural as opposed to thematical terms. ${ }^{104} \mathrm{His}$ suggestion is to read the works of writers like Beckett, lonesco, Genet and Pinter as "ethical parables" which "revolt against existentialism" and "force the audience to make life meaningful." 105 While I personally find the latter points less convincing, and although I may take particular issue with the use of the charged attribute "ethical," the idea of reading these works as parables is very apt. ${ }^{106}$ Indeed, it was put forward 70 years ago by none other than Hildesheimer.

In a 1959 lecture that has rightly been considered "brilliantly persuasive" and "brilliantly argued,"107 Hildesheimer anticipates Esslin in talking about "absurd

101. Esslin, 5-6.

102. Bennett, Cambridge Introduction, 18.

103. Esslin, 24.

104. Bennett, Cambridge Introduction, 3.

105. Bennett, Reassessing the Theatre of the Absurd, 2.

106. For a helpful summary of literature on the parable, see Bennett's "Addendum \#1" (Reassessing the Theatre of the Absurd, 109-123). On the whole I agree with Bennett's definition of parabolic drama: that it is metaphoric, heterotopic, and contradictory, and that its "metonymic paradoxes" are more about asking questions than answering them (Bennett, Reassessing the Theatre of the Absurd, 22-23). However, I believe that the assumption that it must have "an agenda of transformation" (Bennett, Reassessing the Theatre of the Absurd, 22, original emphasis) does not hold up. I side with Esslin in arguing instead that what he called the Theater of the Absurd does not aim to be either socially or morally edifying, in contrast with its "epic" counterpart (Esslin, 341).

107. Wegener, "The Absurd in Modern Literature," 154; and Esslin, 245. High praise indeed, and one that is not always accorded to the rest of his critical output (Stanley, Wolfgang Hildesheimer and His Critics, 108). 
theater" as a designation that might describe much of contemporary drama. His "working hypothesis" is simple: "Every absurd play is a parable." 108 Yet "it is a completely different kind of parable" in that it is "a parable of life," which, like life itself, consists of "a permanent, unanswered question." 109 Evoking Camus, Hildesheimer contends that absurdist theater boils down to "the confrontation between man and the alien world, and hence between man and that question."110 It is, then, "a parable about man's alien status in the universe." ${ }^{111}$ He goes on to add that "only the sum of the absurd plays - that is, the existence of the theater of the absurd as a phenomenon - becomes an analogue of life," so absurdist drama is best seen "as a whole."112

This is another way of concurring with that much-vaunted dictum regarding absurdist literature: that absurdity touches upon a universal reality, namely the human condition. ${ }^{113}$ And the parable is doubtless the best form to deal with such an issue, one that is at once universal (everyone can relate to the parable, because everyone is concerned by the situation depicted in it) and unresolved, indeed unsolvable (neither absurdity itself nor the absurdist parable are in a position to proffer an answer of any kind to the conundrum at hand). Thus, the absurdist parable can be interpreted as a portrayal of the human being facing their condition. Interestingly, and for reasons that will become clearer in this final section, in this context the choice of old age for the representation of the human condition is not surprising at all but in fact very pertinent.

First, however, we must reckon with the issue of contingency: the question of whether old age should be seen as contingent or necessary is hard to settle, because a slight change in perspective can yield quite disparate answers. On the one hand, old age may be seen as "a necessity": "Unless we die first, it is in the nature of time and our condition as biological creatures that we shall grow old." ${ }^{114}$ On the other hand, it may be regarded as "a contingency, though of a rather impure sort," since "it is not certain to be our lot: we may not live to grow old; we may choose not to grow old." ${ }^{115}$ So it might be summed up as "a peculiar

108. Hildesheimer, "On the Theater of the Absurd," 252.

109. Hildesheimer, "On the Theater of the Absurd," 252.

110. Hildesheimer, "On the Theater of the Absurd," 252.

111. Hildesheimer, "On the Theater of the Absurd," 262.

112. Hildesheimer, "On the Theater of the Absurd," 253.

113. See, e.g., Camus, 14; Esslin, 339; Cornwell, 13; Wellwarth, 53.

114. Small, 4.

115. Small, 4, 59. 
kind of contingency - neither fully a contingency, nor quite a necessity." ${ }^{116}$ One might say that such an inconclusive result is to be expected when we approach that kind of inquiry from a philosophical point of view: after all, for existentialists like Sartre and Beauvoir death itself "is a contingent fact." ${ }^{117}$ In this regard, it bears mentioning that the scientific debate over whether "organisms age by design or by mistake . . . is far from over: the pendulum swings back and forth."118 So it seems that we have to conciliate both camps and recognize the complexity of old age, made up as it is of both contingent (external) and existential (inherent) elements. ${ }^{119}$

To say that old age may not be a necessary condition of a given human life, however, is not say that the notion of the universality of old age in general does not stand up to scrutiny. In fact, it could be said that it is one of the few things about it that is not hotly disputed. "According to the anthropologists," for instance, "age is a universal criterion employed in every known society to differentiate and rank persons," for "age is a biological fact of life" - although, of course, it "cannot be described without reference to social situational factors." 120 Thus, even existentialist thinkers like Beauvoir - concerned as they are with the unique, the concrete, the experiential - provide philosophical accounts of old age in "universalist" terms. ${ }^{121}$

From acknowledging the universality of old age to regarding it as part and parcel of our human condition is but a small step. Beckett's view of life "as a process of dying," and of death as perhaps less of "an ending, a boundary, or even an event at all" than we would ordinarily presume, ${ }^{122}$ lends itself to a shift of emphasis from death ${ }^{123}$ to old age: as Elizabeth Barry observes, in the Irish writer's oeuvre "the condition associated with old age is seen simply as an amplification of the general one." ${ }^{124}$ Indeed, aging and meaning-making are often

116. Small, 59.

117. Arp, "Old Age in Existentialist Perspective," 140.

118. Mangan, Staging Ageing, 183.

119. Baars, Aging and the Art of Living, 243.

120. Henricks and Leedham, "Making Sense," 6, 1.

121. Davis, 48.

122. Barry, "Beckett, Augustine, and the Rhetoric of Dying," 82.

123. See Paul Stewart's thought-provoking suggestion to approach Beckett's work with a greater focus on the ideas of sterility and extinction rather than on death as a personal experience (Stewart, "Sterile Reproduction," 172).

124. Barry, "The Ageing Body," 140. 
intertwined processes, as "[o]ld age is a time when we are likely to come face-toface with questions about ultimate meaning." 125

Thomas Rentsch's thoughts on old age are particularly illuminating: he best expresses what is at work in the plentiful absurdist works that thematize old age. Rentsch describes life as "a process of finitization," and therefore aging as "the process of man becoming himself within a finite, unique life-situation." 126 Since "the complex processes of protecting and testing identity" do not cease upon reaching adulthood but on the contrary become more important than ever before, he believes that "the process of aging intensifies the experience of finitude." 127 The process of aging, then, "is the radicalization of the basic human condition." 128

The extent to which that last phrase sums up the use of the theme of old age in the works of practitioners of the absurd such as Beckett, Pinter, Pinget, Ionesco, and Hildesheimer is truly remarkable. What is also striking is how Beauvoir, in an oft-neglected moment of inspiration, mused on the prevalence of old age in absurdist drama. Having noted that William Shakespeare's King Lear, almost uniquely in the Western literary canon before the twentieth century, has an old man embody the human condition, ${ }^{129}$ she proceeds to highlight the singular emphasis that absurdist drama places on old age, citing artistic creations by Beckett and Ionesco in particular. ${ }^{130}$ For the French philosopher, in those works, as previously in King Lear, old age is portrayed not as the furthest boundary of the human condition but as the truth of the human condition itself. ${ }^{131}$

Thus, the veil over the dialectical relationship between old age and the absurd by means of the parable begins to be lifted. If living is to be understood, as I believe it should, in tandem with aging, that is, as "a universal and continuous process of living in time"; 132 if any "philosophical sense of absurdity . . must arise from the perception of something universal"; ${ }^{133}$ if "the search of meaning" is not

125. Moody, Aging, 109.

126. Rentsch, "Aging as Becoming Oneself," 347.

127. Rentsch, 353, 355.

128. Rentsch, 358.

129. Beauvoir, 175, 179.

130. Beauvoir, 225-226.

131. Beauvoir, 226.

132. Baars, "Problematic Foundations," 87.

133. Nagel, "The Absurd," 718. 
only "uniquely human" but one of the "characteristic qualities of old age"; ${ }^{134}$ and if the parable, by dint of its oblique nature, is one of the most suitable means to represent the unhappy coincidence of that search of meaning and its actual absence; then the link between the theme of old age and the philosophical concept of the absurd begins to appear not as the mere fruit of chance but as the predictable outcome of an unassailable theoretical synergy.

This enticing research direction is well worth pursuing, and not just because too few have done it before. Davis notes that "reading about the aging process will always be an attempt to confront with lucidity one facet of the inherent ambiguity of the human condition." ${ }^{135}$ So reading about old age in conjunction with the "hitherto unsolved" problem of the absurd ${ }^{136}$ may prove to be twice as enlightening, not only in order to enrich our understanding of an important "disposition" of the twentieth century, but also, hopefully, the better to come to terms with the frailty of our condition.

\section{Bibliography}

Ackerley, G. J. and S. E. Gontarski. The Grove Companion to Samuel Beckett: A Reader's Guide to His Works, Life, and Thought. New York: Grove Press, 2004.

Adamov, Arthur. Théâtre II: Le Sens de la Marche, Les Retrouvailles, Le Ping-Pong. Paris: Gallimard, 1955.

Anemone, Anthony. "The Anti-World of Daniil Kharms: On the Significance of the Absurd." In Daniil Kharms and the Poetics of the Absurd: Essays and Materials, 49-70. Edited by Neil Cornwell. New York: St. Martin's Press, 1991.

Ariès, Philippe. Western Attitudes Toward Death From the Middle Ages To the Present. Translated by Patricia M. Ranum. Baltimore, London: John Hopkins University Press, 1974.

134. Moody, Aging, 109.

135. Davis, 195.

136. Schaper, 84 (my translation). 
Arp, Kristana. "Old Age in Existentialist Perspective." In The Palgrave Handbook of the Philosophy of Ageing, 135-148. Edited by Geoffrey Scarre. London: Palgrave Macmillan, 2017.

Baars, Jan. Aging and the Art of Living. Baltimore: Johns Hopkins University Press, 2012.

Baars, Jan. "Problematic Foundations: Theorizing Time, Age, and Aging." In Handbook of Theories of Aging, 87-99. Edited by L. Vern Bengtson, Daphna Gans, Norella M. Putney, and Merril Silverstein. New York: Springer, 2009.

Barfield, Steven, Matthew Feldman, and Philip Tew, eds. Beckett and Death. London: Continuum, 2009.

Barry, Elizabeth. "The Ageing Body." In The Cambridge Companion to the Body in Literature, 132-148. Edited by David Hillman and Ulrika Maude. Cambridge: Cambridge University Press, 2015.

Barry, Elizabeth. "Beckett, Augustine, and the Rhetoric of Dying." In Beckett and Death, 72-88. Edited by Steven Barfield, Matthew Feldman, and Philip Tew. London: Continuum, 2009.

Bavidge, Michael. "Feeling One's Age: A Phenomenology of Aging." In The Palgrave Handbook of the Philosophy of Ageing, 207-224. Edited by Geoffrey Scarre. London: Palgrave Macmillan, 2017.

Beauvoir, Simone de. La Vieillesse. Paris: Gallimard, 1970.

Beckett, Samuel. The Complete Dramatic Works. London: Faber and Faber, 2006.

Bennett, Alice. Afterlife and Narrative in Contemporary Fiction. New York: Palgrave Macmillan, 2012.

Bennett, Michael. Reassessing the Theatre of the Absurd: Camus, Beckett, Ionesco, Genet, and Pinter. New York: Palgrave Macmillan, 2011.

Bennett, Michael. The Cambridge Introduction to Theatre and Literature of the Absurd. Cambridge: Cambridge University Press, 2015. 
Botelho, Lynn A. "The 17th Century." In A History of Old Age, 113-175. Edited by Pat Thane. London: Thames \& Hudson and J. Paul Getty Museum, 2005.

Brivic, Shelly. "The Third Policeman as Lacanian Deity: O'Brien's Critique of Language and Subjectivity." New Hibernia Review 16 (2012): 112-132.

Camus, Albert. The Myth of Sisyphus. Translated by Justin O'Brien. London: Penguin, 2005.

Cioran, Emile. A Short History of Decay. Translated by Richard Howard. New York: Arcade, 2012.

Cornwell, Neil. The Absurd in Literature. Manchester, New York: Manchester University Press, 2006.

Davis, Oliver. Age Rage and Going Gently: Stories of the Senescent Subject in Twentieth-Century French Writing. Amsterdam, New York: Rodopi, 2006.

Esslin, Martin. The Theatre of the Absurd. London, New Delhi, New York, Sydney: Bloombsury, 2014.

Fotiade, Ramona. Conceptions of the Absurd: From Surrealism to the Existential Thought of Chestov and Fondane. Oxford: Legenda, 2001.

Gavins, Joanna. Reading the Absurd. Edinburgh: Edinburgh University Press, 2013.

Gerould, Daniel. "Contexts for Vatzlav: Mrozek and the Eighteenth Century." Modern Drama 27 (1984): 21-40.

Giaquinta, Rosanna. "Elements of the Fantastic in Daniil Kharms's Starukha." In Daniil Kharms and the Poetics of the Absurd: Essays and Materials, 132148. Edited by Neil Cornwell. New York: St. Martin's Press, 1991.

Görner, Rüdiger. Die Kunst des Absurden: Über ein literarisches Phänomen. Darmstadt: Wissenschaftliche Buchgesellschaft, 1996. 
Henricks, Jon and Cynthia Leedham. "Making Sense: Interpreting Historical and Cross-Cultural Literature on Aging." In Perceptions of Aging in Literature: A Cross-Cultural Study, 1-16. Edited by Prisca von Dorotka Bagnell and Patricia Spencer Soper. New York, Westport, London: Greenwood, 1989.

Hildesheimer, Wolfgang. Gesammelte Werke in sieben Bänden - Band VII: Vermischte Schriften. Edited by Christiaan Lucas Hart Nibbrig and Volker Jehle. Frankfurt am Main: Suhrkamp, 1991.

Hildesheimer, Wolfgang. Die Hörspiele. Frankfurt am Main: Suhrkamp, 1988.

Hildesheimer, Wolfgang. "On the Theater of the Absurd." In Essays on German Theater: Lessing, Brecht, Dürrenmatt, and Others, 250-263. Edited by Margaret Herzfeld-Sander. New York: Continuum, 1985.

Hinchliffe, Arnold. The Absurd. London: Methuen, 1969.

Hughes, Julian. "The Physiology and Psychology of Aging: Should Aging Be Successful or Authentic?" In The Palgrave Handbook of the Philosophy of Ageing, 49-68. Edited by Geoffrey Scarre. London: Palgrave Macmillan, 2017.

Jaccard, Jean-Philippe. "Daniil Kharms in the Context of Russian and European Literature of the Absurd." In Daniil Kharms and the Poetics of the Absurd: Essays and Materials, 49-70. Edited by Neil Cornwell. New York: St. Martin's Press, 1991.

Jochum, Klaus Peter. "'Old Men Ought to Be Explorers': The Poet and Old Age." In Old Age and Ageing in British and American Culture and Literature, 15-28. Edited by Christa Jansohn. Münster: Lit, 2004.

Kharms, Daniil. "I Am a Phenomenon Quite Out of the Ordinary": The Notebooks, Diaries and Letters of Daniil Kharms. Translated and edited by Anthony Anemone and Peter Scotto. Brighton: Academic Studies Press, 2013.

Kharms, Daniil. Today I Wrote Nothing: The Selected Writings of Daniil Kharms. Edited and translated by Matvei Yankelevich. New York, Woodstock, London: Overlook Duckworth, 2007. 
Lioure, Michel. "Le Vieux." In Dictionnaire Eugène Ionesco, 632. Edited by Jeanyves Guérin. Paris: Honoré Champion, 2012.

Lioure, Michel. "Les Chaises." In Dictionnaire Eugène lonesco, 120-127. Edited by Jeanyves Guérin. Paris: Honoré Champion, 2012.

Mangan, Michael. Staging Ageing: Theatre, Performance and the Narrative of Decline. Bristol, Chicago: Intellect, 2013.

Matthews, Steven. "Beckett's Late Style." In Beckett and Death, 188-205. Edited by Steven Barfield, Matthew Feldman, and Philip Tew. London: Continuum, 2009.

Moody, Harry. "The Meaning of Life and the Meaning of Old Age." In What Does It Mean to Grow Old? Reflections from the Humanities, 9-40. Edited by Thomas R. Cole and Sally A. Gadow. Durham: Duke University Press, 1986.

Moody, Harry. Aging: Concepts and Controversies. Thousand Oaks, London, New Delhi: Pine Forge, 2006.

Nagel, Thomas. "The Absurd." The Journal of Philosophy 68 (1971): 716-727.

Nathanson, Stephen. The Ideal of Rationality: A Defense, within Reason. Chicago, La Salle: Open Court, 1994.

Parkin, Tim. "The Ancient Greek and Roman Worlds." In A History of Old Age, 3170. Edited by Pat Thane. London: Thames \& Hudson and J. Paul Getty Museum, 2005.

Pinget, Robert. Lettre morte : suivi de La manivelle : pièce radiophonique. Paris: Minuit, 1970.

Pinter, Harold. Plays: One: The Birthday Party, The Room, The Dumb Waiter, A Slight Ache, A Night Out, The Black and White, The Examination. London: Eyre Methuen, 1976. 
Querido, Pedro. "Considering Old Age and the Absurd in Harold Pinter's A Slight Ache." The Harold Pinter Review 2 (2018): 59-81.

Querido, Pedro. "From Kharms to Camus: Towards a Definition of the Absurd as Resistance." Modern Language Review 112 (2017): 765-792.

Reid, Martine. "Robert Pinget." Yale French Studies, Special Issue: After the Age of Suspicion: The French Novel Today (1988): 97-100.

Rentsch, Thomas. "Aging as Becoming Oneself: A Philosophical Ethics of Late Life." In The Palgrave Handbook of the Philosophy of Ageing, 347-364. Edited by Geoffrey Scarre. London: Palgrave Macmillan, 2017.

Ricks, Christopher. Beckett's Dying Words. Oxford: Claredon Press, 1993.

Rooke, Constance. "Old Age in Contemporary Fiction: A New Paradigm of Hope." In Handbook of the Humanities and Aging, 241-257. Edited by Thomas R. Cole, David D. Van Tassel and Robert Kastenbaum. New York: Springer, 1992.

Said, Edward. On Late Style. London: Bloomsbury, 2006.

Schaper, Susanne. Ironie und Absurdität als philosophische Standpunkte. Würzburg: Königshausen \& Neumann, 1994.

Small, Helen. The Long Life. Oxford: Oxford University Press, 2007.

Stanley, Patricia. Wolfgang Hildesheimer and His Critics. Columbia: Camden House, 1993.

Stewart, Paul. "Sterile Reproduction: Beckett's Death of the Species and Fictional Regeneration." In Beckett and Death, 169-187. Edited by Steven Barfield, Matthew Feldman, and Philip Tew. London: Continuum, 2009.

Thane, Pat. "The Age of Old Age." In A History of Old Age, 9-30. Edited by Pat Thane. London: Thames \& Hudson and J. Paul Getty Museum, 2005. 
Thomas, Joyce. "There Was an Old Man...': The Sense of Nonsense Verse." Children's Literature Association Quarterly 10 (1985): 119-122.

Wegener, Adolph. "The Absurd in Modern Literature." Books Abroad 41 (1967): 150-156.

Wellwarth, George. The Theater of Protest and Paradox: Developments in the Avant-Garde Drama. New York: New York University Press, 1964.

White, Kathryn. Beckett and Decay. London: Continuum, 2009.

Woodward, Kathleen. "Transitional Objects and the Isolate: Samuel Beckett's Malone Dies." Contemporary Literature 26 (1985): 140-154. 